\title{
PENGARUH KOMPETENSI PUSTAKAWAN TERHADAP KUALITAS LAYANAN PERPUSTAKAAN UNIVERSITAS JEMBER
}

\section{INFLUENCE OF LIBRARY COMPETENCY OF SERVICE COURSE LIBRARY OF JEMBER UNIVERSITY}

\author{
Khusnun Nadhifah, \\ Pustakawan UPT Perpustakaan Universitas Jember \\ Jl. Kalimantan 37 Jember Jawa Timur 68121 \\ Email: Khusnun.Library@gmail.com ; 082333118148
}

\begin{abstract}
ASEAN Economic Community (AEC), ), triggers intense competition for labor. This requires the quality of human resources, including competent librarians who can provide satisfying service quality.Facing these conditions, we need quality services that can satisfy library users / users, namely competencies of librarians. Actual conditions shows the visitor dissatisfaction to UNEJ Library service. This study aims to analyze the effect of librarian competence on service quality, using quota sampling method with quantitative approach of 11,528 library visitors from January to February 2019 and 100 respondents as a sample. By analysis using SmartPLS 2 (Partial Least Square) software, it is known that librarian competence significantly influences the service quality with a percentage of $83.1 \%$. The greatest value is shown in knowledge indicator, the Librarian understands about service (X1.1) with a percentage of $76 \%$. Whereas, Librarian Competency variable $(X)$ which has an indirect effect on service quality is the Librarian Indicator Fun in Serving (X2.1) of 92.12\%.
\end{abstract}

Keywords: librarian competence, service quality, library

\begin{abstract}
ABSTRAK
Masyarakat Ekonomi ASEAN (MEA), memicu persaingan ketat terhadap tenaga kerja. Untuk itu diperlukan kualitas SDM, termasuk pustakawan yang kompeten yang dapat memberikan kualitas layanan yang memuaskan.. Kondisi lapangan menunjukkan ketidakpuasan pengunjung pada layanan Perpustakaan UNEJ. Penelitian ini bertujuan menganalisis pengaruh kompetensi pustakawan terhadap kualitas layanan. Penelitian menggunakan metode sampling kuota, dengan pendekatan kuantitatif pada 11.528 populasi pengunjung perpustakaan bulan Januari-Pebruari 2019 dan sampel berjumlah 100 responden. Dengan analisis menggunakan software SmartPLS 2 (Partial Least Square) diketahui bahwa Kompetensi Pustakawan berpengaruh secara signifikan terhadap Kualitas Layanan dengan peresentase 83,1\%. Nilai terbesar ditunjukkan pada indikator pengetahuan, yaitu Pustakawan memahami tentang pelayanan $\left(X_{1.1}\right)$ dengan persentase $76 \%$. Sedangkan, variabel Kompetensi Pustakawan (X) yang berpengaruh secara tidak langsung terhadap kualitas layanan adalah pada indikator Pustakawan Menyenangkan dalam Melayani (X2.1) sejumlah $92,12 \%$.
\end{abstract}

Kata Kunci : kompetensi pustakawan, kualitas layanan, perpustakaan 


\section{PENDAHULUAN}

Masyarakat Ekonomi ASEAN (MEA) merupakan pasar bebas yang memberikan dampak positif pada masyarakat Indonesia yaitu membuka lapangan pekerjaan baru, kemudahan mencari pekerjaan di negara ASEAN. Sedangkan dampak negatifnya adalah tenaga kerja asing dengan mudah masuk ke Indonesia sehingga terjadi persaingan ketat terhadap tenaga kerja (Prasetyo, 2012). Salah satu isu terkait implementasi MEA adalah kesiapan sumber daya manusia (SDM). Untuk itu diperlukan pembenahan kualitas SDM sebagai faktor penentu keberhasilan pembangunan dan kemajuan suatu bangsa. (Wuryandani, 2015).

Dampak pada kalangan akademisi adalah terjalin kerjasama Universitas Jember (UNEJ) dengan perguruan tinggi antar negara seperti kerja sama dengan Kyungpook National University (KNU) di Korea Selatan. Beberapa fakultas di UNEJ juga menyelenggarakan program pendidikan internasional baik sarjana maupun pascasarjana (www.unej.ac.id).

Pemenuhan kebutuhan generasi milenial, terutama kebutuhan teknologi dan informasi menuntut SDM yang berkualitas. Generasi milenial adalah generasi yang sangat mahir di bidang teknologi seperti penggunaan telepon seluler, komputer, laptop dan akses terhadap internet (Budiati, 2018). Shahreza (2017) mengelompokkan generasi menjadi 6 yaitu Generasi Traditionalist (1928-1945), Generasi Baby Boomer (1946-1964), Generasi X (19651976), Generasi Y (1977-1998), Generasi Z (1999-2012) dan Generasi Alpha (20132025). Generasi Y dan generasi Z/ Generation Net adalah rata-rata usia mahasiswa sebagai pengunjung utama di UPT Perpustakaan UNEJ. Sebagai gambaran kondisi pengunjung UPT Perpustakaan UNEJ dalam kurun waktu Januari-Pebruari 2019 adalah sebagai berikut:

Tabel 1.1 Pengunjung UPT Perpustakan UNEJ, 2019

\begin{tabular}{|l|c|c|}
\hline Member Type & Januari & Pebruari \\
\hline Mahasiswa & 3.999 & 7.529 \\
\hline Dosen Kontrak & 3 & 1 \\
\hline Dosen & 7 & 10 \\
\hline Pegawai & 0 & 1 \\
\hline Karyawan & 45 & 26 \\
\hline Pasca sarjana & 66 & 93 \\
\hline $\begin{array}{l}\text { Mahasiswa Umum / Non } \\
\text { UNEJ }\end{array}$ & 96 & 140 \\
\hline Tamu & 5 & 4 \\
\hline Alumni UNEJ & 21 & 12 \\
\hline NON-Member Visitor & 3 & 4 \\
\hline Total Visit/Month & 4.245 & 7.820 \\
\hline
\end{tabular}

Sumber: Library.unej.ac.id, 2019

Berdasarkan tabel 1 jumlah pengunjung mengalami kenaikan. Hal ini dipengaruhi masa aktif perkuliahan serta penerimaan mahasiswa baru. Selain itu fasilitas dan kualitas layanan juga berpengaruh terhadap jumlah pengunjung (Rosita, Marhanah, \& Wahadi, 2016). Semakin berkualitas fasilitas dan layanan yang diberikan akan memberikan kepuasan kepada pengunjung perpustakaan.

Penelitian ini menggunakan pengukuran kualitas layanan dalam 7 faktor yaitu Tangible, Empathy, Reliability, Respon, Siveness, Assurance, Consumer Satisfaction dan Consumer Loyalty (Aryani \& Rosinta, 2010). Sedangkan kondisi kompetensi pustakawan di UPT Perpustakaan UNEJ dapat dilihat pada tabel 2 
Tabel 2 Kompetensi Pustakawan UNEJ

\begin{tabular}{|l|l|l|l|l|l|l|l|}
\hline \multirow{2}{*}{ No. } & \multirow{2}{*}{$\begin{array}{c}\text { Pendidikan } \\
\text { Pustakawan }\end{array}$} & \multirow{2}{*}{ Jumlah } & \multirow{2}{*}{$\begin{array}{c}\text { Uji } \\
\text { Sertifikasi }\end{array}$} & \multirow{2}{*}{$\begin{array}{c}\text { Uji } \\
\text { Kompetensi }\end{array}$} & \multicolumn{3}{|c|}{ Prosentase (\%) } \\
\cline { 6 - 8 } & & & & Pendidikan & Sertifikasi & Kompetensi \\
\hline 1 & S2 & 4 & 3 & 3 & 26,67 & 20 & 20 \\
\hline 2 & S1 & 6 & 1 & 2 & 40 & 6,67 & 13,33 \\
\hline 3 & D3 & 0 & 0 & 0 & 0 & 0 & 0 \\
\hline 4 & D2 & 5 & 0 & 0 & 33,33 & 0 & 0 \\
\hline & JUMLAH & 15 & 4 & 5 & 100 & 26,67 & 33,33 \\
\hline
\end{tabular}

Sumber: UPT Perpustakaan UNEJ, 2019

Berdasarkan fenomena di atas, pustakawan harus mempunyai kualifikasi khusus dan dapat beradaptasi dengan era dan generasi digital atau generasi Y, mempunyai pola pikir cerdas, kreatif serta inovatif dalam menyikapi permasalahan serta tantangan di bidangnya (Kurniasih, 2015). Berdasar observasi dan kritik pada kotak saran mahasiswa ada yang mengatakan bahwa pelayanan di UPT Perpustakaan UNEJ kurang memuaskan. Oleh karena itu dibutuhakan sebuah penelitian tentang pengaruh kompetensi pustakawan terhadap kualitas layanan. Rumusan masalah dalam penelitian ini adalah "Bagaimana pengaruh kompetensi pustakawan terhadap kualitas layanan Perpustakaan UNEJ? Tujuan Penelitian yaitu menganalisis pengaruh kompetensi pustakawan terhadap kulaitas layanan Perpustakaan UNEJ.

\section{Kompetensi Pustakawan}

Kompetensi menurut Standar Kerja Nasional Indonesia (SKKNI) Perpustakaan Nasional RI adalah kemampuan seseorang yang mencakup pengetahuan, keterampilan dan sikap kerja yang dapat terobservasi dalam menyelesaikan pekerjaan sesuai dengan standar kinerja yang ditetapkan. SKKNI membagi kompetensi dalam 3 kelompok, yaitu 1) Kelompok Kompetensi Umum, yaitu kompetensi yang harus dimiliki pustakawan, 2) kompetensi inti adalah kompetensi fungsional yang harus dimiliki pustakawan dalam menjalankan tugas-tugas perpustakaan. 3)
Kompetensi khusus merupakan kompetensi tingkat lanjut yang bersifat spesifik (Perpustakaan Nasional RI, 2012)

Suwarno (2016) menyatakan bahwa pengembangan pustakawan harus berbasis kompetensi yaitu pengetahuan/cognition, sikap/ fection, dan kreativitas/phsychomotoric.untuk mencapai tujuan dan sasaran perpustakaan sesuai dengan standar kinerja yang ditentukan. Kompetensi akan memberikan dukungan terhadap perkembangan perpustakaan.

\section{Layanan Perpustakaan}

Menurut Perpustakaan Nasional RI (2017), pelayanan perpustakaan adalah kegiatan memberikan bimbingan, jasa perpustakaan dan informasi kepada pemustaka yang meliputi pelayanan teknis dan pelayanan pemustaka. Pelayanan teknis adalah kegiatan yang terkait dengan pengembangan koleksi, pengolahan bahan perpustakaan, penyimpanan dan perawatan koleksi perpustakaan. Pelayanan pemustaka adalah kegiatan yang berkaitan dengan jasa informasi perpustakaan yang dapat dimanfaatkan pemustaka. seperti layanan peminjaman dan pengembalian koleksi.

\section{METODE PENELITIAN}

Penelitian tergolong sebagai Explanatory Research, yaitu penelitian yang menganalisis hubungan kausal dan menguji keterkaitan antara beberapa variabel malalui pengujian hipotesis atau penelitian penjelasan (Singarimbun, 1989). Populasi berjumlah 11.528 mahasiswa yang 
berkunjung ke UPT Perpustakaan UNEJ bulan Januari - Pebruari 2019. Pengambilan sampel menggunakan metode sampling kuota yaitu teknik pengambilan sampel dengan menentukan jumlah sampel dari populasi dengan mempunyai ciri tertentu yaitu mahasiswa UNEJ yang meminjam pada bulan Januari-Pebruari 2019 sampai jumlah kuota yang ditentukan yaitu 100 peminjam. Jumlah sampel adalah100 peminjam. Skala pengukuran adalah ordinal dengan Skala Likert (Likert Scale) dengan skor antara 1 (sangat negatif) sampai 5 (sangat positif), yaitu : Sangat Setuju (SS) = 5, Setuju (S) = 4, Kurang Setuju $(\mathrm{KS})=3$, Tidak Setuju $(\mathrm{TS})=2$, Sangat Tidak Setuju $($ STS $)=1$. Prosedur Pengumpulan data dilakukan dengan kuesioner, observasi, dan serta studi pustaka. Data penelitian berasal dari data primer dan sekunder. Data dianalisis menggunakan SmartPLS 3 (Partial Least Square)2 (Ghozali \& Latan, 2012).

\section{ANALISIS HASIL PENELITIAN DAN PEMBAHASAN}

Hasil penelitian memberikan data umum sebagai berikut:

1. Karakter sampel berdasar jenis kelamin.

Hasil penelitian menunjukkan bahwa frekewensi berkunjung ke Perpustakaan UNEJ mayoritas adalah perempuan (mahasiswi) sejumlah 79\%, dan lakilaki (mahasiswa) sejumlah 21\%. Data menunjukkan bahwa frekwensi berkunjung perempuan lebih tinggi dibanding laki-laki. Menurut (Anggraini, 2015) bahwa aspek Regulasi Diri dalam Belajar (Self regulated learning) merupakan strategi dan upaya seseorang dalam belajar melalui monitor diri untuk mendapatkan hasil belajar yang diinginkan melaui kemampuan metakognisi yaitu kemampuan seseorang untuk 1) Meregulasi diri melalui perencanaan, pengorganisasian, instruksi diri, memonitor dan evalusi diri dalam proses belajar, 2) Memotivasi diri sendiri, reaksi dalam mencapai tujuan berupa pemikiran, usaha serta ketekunan melaksanan tugas, 3) Perilaku mengatur diri, seleksi dan menciptakan lingkungan yang bermanfaat. Hasil penelitian menunjukkan bahwa self regulated learning perempuan mempunyai metakognisi, motivasi dan perilaku yang lebih tinggi dalam belajar dibanding laki-laki. Salah satu kegiatan dalam self regulated learning adalah berkumjung ke perpustakaan dalam rangka memotivasi diri yaitu belajar dan menciptakan lingkungan yang bermanfaat dalam mendukung aktivitasnya.

2. Karakter sampel berdasar jenis jenjang Pendidikan.

Hasil penelitian menunjukkan frekwensi kunjungan mahasiswa program sarjana lebih banyak (91\%) dibanding dengan mahasiswa program pasca sarjana $(9 \%)$.

3. Karakter sampel berdasar frekwensi kunjungan ke perpustakaan.

Hasil penelitian menunjukkan bahwa sampel tertinggi adalah pada mahasiswa dengan kunjungan lebih dari 12 kali dalam setahun (90\%). Frekwensi kunjungan lebih dari 12 kali dalam setahun menunjukkan mahasiswa sering berkunjung dan memahami karakter pustakawan serta layanan di UPT Perpustrakaan UNEJ.

4. Karakter sampel berdasar fakultas pemustaka

Hasil penelitian menunjukkan bahwa mahasiswa Fakultas Keguruan dan Ilmu Pendidikan terbanyak berkunjung ke perpustakaan (33\%). Persentase frekwensi berkunjung ke perpustakaan terkecil adalah FMIPA (1\%). 


\section{Deskripsi Variabel Penelitian.}

Deskripsi penilaian Kompetensi

Pustakawan dapat dilihat pada tabel 3.

Tabel 3 Penilaian Subyek Peneliti Terhadap

Variabel Kompetensi Pustakawan

\begin{tabular}{|l|c|c|c|c|c|c|c|c|c|c|}
\hline \multicolumn{1}{|c|}{ PERNYATAAN } & \multicolumn{7}{|c|}{ Jawaban Subyek Peneliti } \\
\hline \multicolumn{1}{|c|}{ Kompetensi pustakawan $(\mathrm{X})$} & $\mathrm{STS}$ & $\%$ & $\mathrm{TS}$ & $\%$ & $\mathrm{KS}$ & $\%$ & $\mathrm{~S}$ & $\%$ & $\mathrm{SS}$ & $\%$ \\
\hline Pengetahuan $\left(\mathrm{X}_{1}\right)$ & & & & & & & & & & \\
\hline Pustakawan memahami pelayanan perpustakaan $\left(\mathrm{X}_{1.1}\right)$ & 1 & 1 & 3 & 3 & 6 & 6 & $\mathbf{6 4}$ & 64 & 26 & 26 \\
\hline $\begin{array}{l}\text { Pustakawan mampu mengoperasionalkan komputer dan } \\
\text { teknologi lain di perpustakaan }\left(\mathrm{X}_{1.2}\right)\end{array}$ & 1 & 1 & 2 & 2 & 2 & 2 & $\mathbf{6 5}$ & 65 & 30 & 30 \\
\hline $\begin{array}{l}\text { Pustakawan memahami kebutuhan referensi pemustaka/ } \\
\left(\mathrm{X}_{1.3}\right)\end{array}$ & 2 & 2 & 2 & 2 & 27 & 27 & $\mathbf{5 3}$ & 53 & 16 & 16 \\
\hline Ketrampilan Interpersonal $\left(\mathrm{X}_{2}\right)$ & $\mathrm{STS}$ & $\%$ & $\mathrm{TS}$ & $\%$ & $\mathrm{KS}$ & $\%$ & $\mathrm{~S}$ & $\%$ & $\mathrm{SS}$ & $\%$ \\
\hline Pustakawan menyenangkan dalam melayani $\left(\mathrm{X}_{2.1}\right)$ & 2 & 2 & 3 & 3 & 25 & 25 & $\mathbf{5 1}$ & 51 & 19 & 19 \\
\hline Pustakawan proaktif membantu pemustaka $\left(\mathrm{X}_{2.2}\right)$ & 0 & 0 & 9 & 9 & 28 & 28 & $\mathbf{4 6}$ & 46 & 17 & 17 \\
\hline $\begin{array}{l}\text { Pustakawan memberikan saran/solusi ketika pemustaka } \\
\text { mengalami masalah layanan }\left(\mathrm{X}_{2.3}\right)\end{array}$ & 1 & 1 & 3 & 3 & 15 & 15 & $\mathbf{6 0}$ & 60 & 21 & 21 \\
\hline Sikap Profesional $\left(\mathrm{X}_{3}\right)$ & $\mathrm{STS}$ & $\%$ & $\mathrm{TS}$ & $\%$ & $\mathrm{KS}$ & $\%$ & $\mathrm{~S}$ & $\%$ & $\mathrm{SS}$ & $\%$ \\
\hline $\begin{array}{l}\text { Pustakawan selalu mengecek kartu anggota/KTM pada } \\
\text { saat melakukan peminjaman }\left(\mathrm{X}_{3.1}\right)\end{array}$ & 0 & 0 & 0 & 0 & 9 & 9 & $\mathbf{4 6}$ & 46 & 45 & 45 \\
\hline $\begin{array}{l}\text { Pustakawan melakukan pengawasan terhadap } \\
\text { pelanggaran peminjam koleksi }\left(\mathrm{X}_{3.2}\right)\end{array}$ & 2 & 2 & 0 & 0 & 8 & 8 & $\mathbf{5 5}$ & 55 & 35 & 35 \\
\hline $\begin{array}{l}\text { Pustakawan fokus melayani pemustaka (tidak sambil } \\
\text { menerima telepon, menggunakan sosial media, main } \\
\text { game dll) }\left(\mathrm{X}_{3.3}\right)\end{array}$ & 1 & 1 & 1 & 1 & 18 & 18 & $\mathbf{5 6}$ & 56 & 24 & 24 \\
\hline
\end{tabular}

Sumber: UPT Perpustakaan UNEJ, Data diolah, 2019

Berdasar tabel 3, nilai tertinggi dengan indikator "Pustakawan Mampu Mengoperasionalkan Komputer dan Teknologi Lain di Perpustakaan" $\left(\mathrm{X}_{1.2}\right)$, masuk kategori setuju $=95 \%$ (setuju $=65 \%$ dan sangat setuju $=$ $35 \%$ ) Hal ini menunjukkan bahwa Pustakawan UNEJ kompeten, tidak gagap teknologi. Familiar dengan dunia komputer dan teknologi lain yang terdapat di perpustakaan, misal melayani pemustaka dengan menggunakan teknologi Radio Frequensi Identificatin (RFID). RFID menurut Karygiannis (2007) adalah bagian dari Radio Frequensi (RF) berfungsi sebagai media identifikasi secara wireless (tanpa kabel) yang terdiri dari dua komponen yaitu 1) RFID tag (tranfonder) yaitu alat (device) kecil yang tertanam pada setiap buku seperti label/tag, berguna untuk mengidentifikasi keunikan, dan 2) RFID reader yaitu device yang berfungsi sebagai komunikasi tanpa kontak langsung (wireless) pada radio frequensi. Selain itu, Pustakawan UNEJ juga mampu melayani menggunakan Online Public Catalogue (OPAC). OPAC merupakan database yang terdiri dari banyak record catalog, dapat diakses langsung para pencari informasi yang berfungsi sebagai katalog terpasang (online catalog) di perpustakaan (Lasa, 1998).

Nilaitertinggipadaindikator"Pustakawan Memberikan Saran/Solusi ketika Pemustaka Mengalami Masalah Layanan" $\left(\mathrm{X}_{2.3}\right)$ masuk kategori setuju $=81 \%$ (setuju $=60 \%$ dan sangat setuju $=21 \%$ ). Hal ini menunjukkan 
bahwa Pustakawan UNEJ tidak membiarkan pemustaka begitu saja ketika menemukan pemasalahan dalam layanan pencarian sumber informasi maupun layanan peminjaman dan pengembalian. Solusi permasalahan layanan pencarian sumber informasi dapat teratasi melalui kerja sama Perpustakaan UNEJ dengan lembaga lain dalam pemanfaatan koleksi. Kerja sama tersebut diantaranya adalah kerjasama dengan Perpustakaan Nasional, Garba Rujukan Digital (Garuda), Indonesia OneSearch (IOS). Perpustakaan Nasional menyediakan berbagai macam sumber informasi dan dapat diakses secara terbuka (open access) berupa e-Resources yaitu Proquest, Science Direct dan lain-lain. (http://e-resources.perpusnas. go.id/). Sedangkan Garuda merupakan portal pencari data karya ilmiah berupa skripsi, tesis, disertasi, laporan penelitian, makalah jurnal dan berbagai sumber informasi karya ilmiah lain yang terintegrasi dari perpustakaan di seluruh Indonesia (Aji, 2010). Kerja sama lainnya adalah dengan IOS merupakan sistem penelusuran yang dipelopori oleh Perpustakaan Nasional berbasis open access yang menghubungkan antar perpustakaan di seluruh Indonesia (Fahmi, 2017). Beragamnya kerja sama UPT Perpustakaan UNEJ dengan lembaga lain, memberikan banyak alternatif pencarian sumber informasi yang diberikan kepada pemustaka.

Nilaitertinggipadaindikator"Pustakawan Fokus Melayani Pemustaka (tidak sambil menerima telepon, menggunakan sosial media, main game dll)" $\left(\mathrm{X}_{3.3}\right)$ masuk kategori setuju $=80 \%($ setuju $=56$ dan sangat setuju $=24 \%)$. Hal ini menunjukkan bahwa Pustakawan UNEJ profesional dan memberikan pusat perhatian pada layanan pemustaka.

\section{Kualitas Layanan Perpustakaan UNEJ}

Hasil analisis menunjukkan kualitas layanan Perpustakaan UNEJ dapat dilihat pada tabel 6.

Tabel 4 Penilaian Subyek Peneliti Terhadap

Variabel Kualitas Layanan Perpustakaan

\begin{tabular}{|c|c|c|c|c|c|c|c|c|c|c|}
\hline \multirow{2}{*}{$\begin{array}{c}\text { PERNYATAAN } \\
\text { Kualitas Layanan (Y) }\end{array}$} & \multicolumn{10}{|c|}{ Jawaban Subyek Peneliti } \\
\hline & STS & $\%$ & TS & $\%$ & KS & $\%$ & $\mathrm{~S}$ & $\%$ & SS & $\%$ \\
\hline \multicolumn{11}{|l|}{ Tangible/ Berwujud $\left(\mathrm{Y}_{1}\right)$} \\
\hline $\begin{array}{l}\text { Prasarana (gedung, ruangan, kamar mandi dan fasilitas } \\
\text { lain) bersih dan nyaman }\left(\mathrm{Y}_{1.1}\right)\end{array}$ & 1 & 1 & 3 & 3 & 25 & 25 & 54 & 54 & 17 & 17 \\
\hline $\begin{array}{l}\text { Sarana (komputer, mesin peminjaman, dan peralatan } \\
\text { lain) di perpustakaan dilengkapi dengan teknologi } \\
\text { mutakhir }\left(\mathrm{Y}_{1.2}\right)\end{array}$ & 1 & 1 & 3 & 3 & 16 & 16 & 62 & 62 & 80 & 80 \\
\hline Pustakawan berpenampilan rapi dan baik $\left(\mathrm{Y}_{1.3}\right)$ & 0 & 0 & 2 & 2 & 1 & 1 & 70 & 70 & 27 & 27 \\
\hline $\begin{array}{l}\text { Pustakawan menerapkan 3S (Sapa, Senyum dan Salam) } \\
\left(\mathrm{Y}_{1.4}\right)\end{array}$ & 2 & 2 & 7 & 7 & 41 & 41 & 37 & 37 & 13 & 13 \\
\hline Empathy/Kepedulian $\left(\mathrm{Y}_{2}\right)$ & STS & $\%$ & TS & $\%$ & $\mathrm{KS}$ & $\%$ & $\mathrm{~S}$ & $\%$ & SS & $\%$ \\
\hline $\begin{array}{l}\text { Pustakawan memberi solusi/alternatif referensi yang } \\
\text { relevan dari referensi yang dibutuhkan }\left(\mathrm{Y}_{2.1}\right)\end{array}$ & 1 & 1 & 7 & 7 & 33 & 33 & 45 & 45 & 14 & 14 \\
\hline $\begin{array}{l}\text { Perpustakaan mendukung terhadap kebutuhan } \\
\text { pemustaka }\left(\mathrm{Y}_{2.2}\right)\end{array}$ & 0 & 0 & 3 & 3 & 25 & 25 & 60 & 60 & 12 & 12 \\
\hline Reliability/Kehandalan $\left(\mathrm{Y}_{3}\right)$ & STS & $\%$ & TS & $\%$ & $\mathrm{KS}$ & $\%$ & $\mathrm{~S}$ & $\%$ & SS & $\%$ \\
\hline $\begin{array}{l}\text { Pustakawan mematuhi janji yang ditetapkan } \\
\text { perpustakaan }\left(\mathrm{Y}_{3,1}\right)\end{array}$ & 0 & 0 & 2 & 2 & 15 & 15 & 68 & 68 & 15 & 15 \\
\hline $\begin{array}{l}\text { Pustakawan mencatat/merekam setiap transaksi layanan } \\
\text { di perpustakaan }\left(\mathrm{Y}_{3.2}\right)\end{array}$ & 1 & 1 & 2 & 2 & 6 & 6 & 62 & 62 & 29 & 29 \\
\hline
\end{tabular}




\begin{tabular}{|c|c|c|c|c|c|c|c|c|c|c|}
\hline $\begin{array}{l}\text { Peminjam menemukan dengan cepat referensi/koleksi } \\
\text { yang dibutuhkan }\left(\mathrm{Y}_{3,3}\right)\end{array}$ & 1 & 1 & 6 & 6 & 36 & 36 & 43 & 43 & 14 & 14 \\
\hline Respon Siveness/ Daya Tanggap $\left(\mathrm{Y}_{4}\right)$ & STS & $\%$ & TS & $\%$ & $\mathrm{KS}$ & $\%$ & $\mathrm{~S}$ & $\%$ & SS & $\%$ \\
\hline $\begin{array}{l}\text { Pustakawan mengatasi dengan cepat kesulitan } \\
\text { pemustaka }\left(\mathrm{Y}_{4.1}\right)\end{array}$ & 1 & 1 & 3 & 3 & 34 & 34 & 54 & 54 & 8 & 8 \\
\hline $\begin{array}{l}\text { Pustakawan meluangkan waktu/bersedia untuk } \\
\text { pencarian kebutuhan informasi }\left(\mathrm{Y}_{4.2}\right)\end{array}$ & 2 & 2 & 5 & 5 & 28 & 28 & 51 & 51 & 14 & 14 \\
\hline Assurance/Jaminan $\left(\mathrm{Y}_{5}\right)$ & STS & $\%$ & TS & $\%$ & KS & $\%$ & $\mathrm{~S}$ & $\%$ & SS & $\%$ \\
\hline $\begin{array}{l}\text { Perpustakaan UNEJ merupakan tempat yang nyaman } \\
\text { dalam pencarian sumber informasi }\left(\mathrm{Y}_{51}\right)\end{array}$ & 1 & 1 & 0 & 0 & 8 & 8 & 67 & 67 & 24 & wr \\
\hline $\begin{array}{l}\text { Perpustakaan menjaga keamanan perlengkapan } \\
\text { pemustaka yang dititipkan }\left(\mathrm{Y}_{5,2}\right)\end{array}$ & 0 & 0 & 2 & 2 & 4 & 4 & 60 & 60 & 35 & 35 \\
\hline Consumer Satisfaction/ Kepuasan Pemustaka $\left(\mathrm{Y}_{6}\right)$ & STS & $\%$ & $\mathrm{TS}$ & $\%$ & $\mathrm{KS}$ & $\%$ & $\mathrm{~S}$ & $\%$ & SS & $\%$ \\
\hline Perpustakaan memenuhi harapan pemustaka $\left(\mathrm{Y}_{6.1}\right)$ & 1 & 1 & 0 & 0 & 24 & 24 & 63 & 63 & 12 & 12 \\
\hline Pelayanan di perpustakaan memuaskan $\left(\mathrm{Y}_{6.2}\right)$ & 2 & 2 & 2 & 2 & 14 & 14 & 73 & 73 & 9 & 9 \\
\hline Consumer Loyalty/ Loyalitas Pemustaka $\left(\mathrm{Y}_{7}\right)$ & STS & $\%$ & $\mathrm{TS}$ & $\%$ & $\mathrm{KS}$ & $\%$ & $\mathrm{~S}$ & $\%$ & SS & $\%$ \\
\hline Pemustaka senang datang ke perpustakaan $\left(\mathrm{Y}_{71}\right)$ & 0 & 0 & 1 & 1 & 0 & 0 & 79 & 79 & 20 & 20 \\
\hline $\begin{array}{l}\text { Pemustaka datang kembali ke perpustakaan jika } \\
\text { membutuhkan referensi }\left(\mathrm{Y}_{7.2}\right)\end{array}$ & 0 & 0 & 0 & 0 & 2 & 2 & 56 & 56 & 42 & 42 \\
\hline
\end{tabular}

Sumber: UPT Perpustakaan UNEJ, Data diolah, 2019

Tabel 5 menunjukkan bahwa nilai tertinggi pada indikator "Pustakawan UNEJ Berpenampilan Rapi dan Baik" $\left(\mathrm{Y}_{1.3}\right)=97 \%$ masuk kategori setuju (setuju $=70 \%$ dan sangat setuju $=27 \%$ ). Pustakawan UNEJ memberikan layanan baik dengan berpakaian seragam serta ID Card yang telah ditetapkan oleh UPT Perpustakaan UNEJ.

Nilai tertinggi pada indikator "Perpustakaan Mendukung Terhadap Kebutuhan Pemustaka $\left(\mathrm{Y}_{2.2}\right)=72 \%$ masuk kategori setuju (setuju $=60 \%$ dan sangat setuju $=12 \%$ ). Hal ini menunjukkan bahwa Perpustakaan UNEJ memperhatikan apa yang diperlukam pemustaka tentang sumber informasi dengan komunikasi langsung melalui kotak saran dan form usulan kebutuhan koleksi.

Nilaitertinggipadaindikator"Pustakawan Siap Melayani Sesuai Janji yang Ditetapkan Perpustakaan" $\left(\mathrm{Y}_{3.1}\right)=83 \%$ masuk kategori setuju (setuju $=68 \%$ dan sangat setuju $=15 \%$ ). Hal ini menunjukkan bahwa Pustakawan UNEJ melayani sesuai dengan aturan/tata tertib yang ditetapkan. Membuka layanan dengan jadwal sesuai jadwal yang ditentukan.

Nilaitertinggipadaindikator"Pustakawan Meluangkan Waktu/bersedia untuk Pencarian Kebutuhan Informasi $\left(\mathrm{Y}_{4.2}\right)=65 \%$ masuk kategori setuju (setuju $=51 \%$ dan sangat setuju $=14 \%$ ). Hal ini menunjukkan bahwa Pustakawan UNEJ membantu pemustaka dengan segera dan tanggap terhadap kebutuhan pemustaka. Daya tanggap merupakan salah satu faktor yang mempengaruhi kualitas layanan. Tjiptono (2004) mengatakan bahwa daya tanggap merupakan keinginan petugas membantu pelanggan dan memberikan layanan dengan tanggap. Keluhan konsumen harus cepat dan tepat direspon petugas dan memberi solusi.

Nilai tertinggi pada indikator "Perpustakaan Menjaga Keamanan Perlengkapan Pemustaka yang Dititipkan $\left(\mathrm{Y}_{5.2}\right)$ $=95 \%$ masuk kategori setuju (setuju $=60 \%$ 
dan sangat setuju $=35 \%$ ). Hal ini menunjukkan bahwa Pustakawan UNEJ melayani dengan sopan dan rasa aman sehingga mendapat kepercayaan sehingga tidak menimbulkan rasa ragu dari pemustaka. Pemustaka merasa aman terhadap perlengkapan pemustaka yang disimpan di ruang penitiapan barang/locker.

Nilai tertinggi pada indikator "Pelayanan di Perpustakaan Memuaskan $\left(\mathrm{Y}_{6.2}\right)=82 \%$ masuk kategori setuju (setuju 73\% dan sangat setuju 9\%). Hal ini menunjukkan pemustaka merasa senang dengan layanan di UPT Perpustakaan UNEJ. Kepuasan merupakan perasaan menyenangkan atau mengecewakan terhadap kesan pada kinerja/hasil produk dan harapan (Kotler \& Teguh., 2002). Kualitas produk berpengaruh signifikan terhadap kepuasan konsumen. Salah satu produk yang dihasilkan perpustakaan adalah berupa layanan. Sedangkan konsumen di perpustakaan adalah pemusta (Gaol, Hidayat, \& Sunarti, 2016).

Nilai tertinggi pada indikator "Pemustaka Senang Datang ke Perpustakaan $\left(\mathrm{Y}_{7.1}\right)=99 \%$ masuk kategori setuju (setuju $=79 \%$ dan sangat setuju $=20 \%$ ). Hal ini menunjukkan bahwa pemustaka setia/loyal berkunjung ke UPT Perpustakaan UNEJ. Loyalitas merupakan pelanggan setia terhadap produk yang diberikan oleh badan usaha dan merekomendasikan kepada orang lain dan tidak pengaruh pada pesaing (Griffin, 2005). Kepuasan atas layanan yang disajikam UPT Perpustakaan UNEJ memberi dampak pada loyalitas pemustaka. Kepuasan berpengaruh signifikan terhadap loyalitas. Irawan \& Japarianto (2013) mengatakan bahwa terdapat hubungan positif antara kepuasan dan loyalitas konsumen.

\section{ANALISIS HASIL PENELITIAN}

Sebagai output calculate Algoritma didapatkan model sebagai berikut:

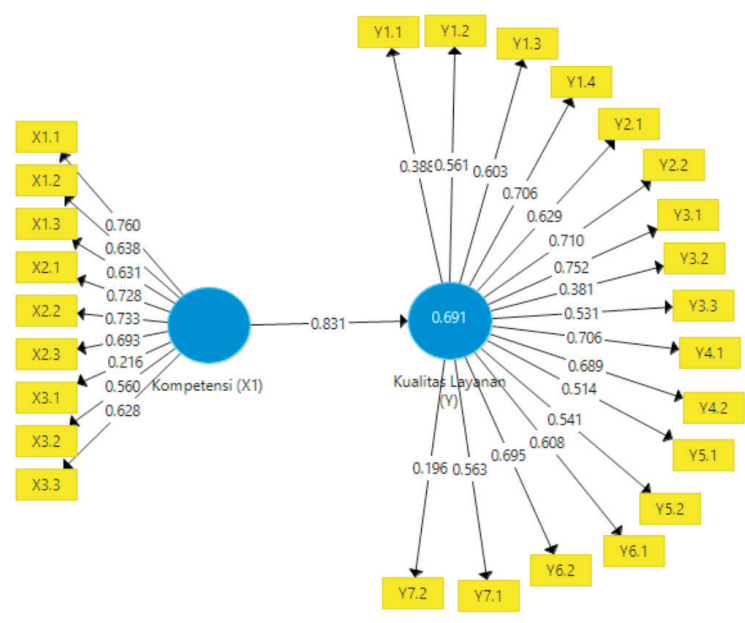

Gambar 1. Perhitungan model struktural (outer model)

Sumber: UPT Perpustakaan UNEJ, Data diolah, 2019

Tabel Output yang menjelaskan hubungan antar varibel laten dapat dilihat pada tabel 7.

Tabel 5 Laten Variable Correlation

\begin{tabular}{|l|c|c|}
\hline & $\begin{array}{c}\text { Kompetensi } \\
\text { Pustakawan (X) }\end{array}$ & $\begin{array}{c}\text { Kualitas } \\
\text { Layanan (Y) }\end{array}$ \\
\hline $\begin{array}{l}\text { Kompetensi } \\
\text { Pustakawan (X) }\end{array}$ & 1,000 & $\mathbf{0 , 8 3 1}$ \\
\hline $\begin{array}{l}\text { Kualitas } \\
\text { Layanan (Y) }\end{array}$ & $\mathbf{0 , 8 3 1}$ & 1,000 \\
\hline
\end{tabular}

Sumber: UPT Perpustakaan UNEJ, Data diolah, 2019

Berdasar gambar 1 dan tabel 7 korelasi antar variabel Kompetensi Pustakawan (X) terhadap varibel Kualitas Layanan Perpustakaan (Y) mempunyai nilai 0,831. Hal 
ini menujukkan bahwa Kompetensi Pustakawan sangat berpengaruh $(83,1 \%)$ terhadap Kualitas Layanan Perpustakaan. Dwirani (2016) mengatakan bahwa kompetensi SDM perpustakaan mempunyai korelasi signifikan dan positif terhadap kualitas layanan digital di perpustakaan SMK Negeri 2 Palembang. Perpustakaan dapat mencapai tujuan yang diharapkan jika terdapat kompetensi SDM yang dapat membantu pemustaka dalam menggunakan layanan digital untuk memenuhi kebutuhan informasi yang dibutuhkan. Sedangkan indikator yang berpengaruh langsung terhadap variabel Kompetensi Pustakawan (X) ditunjukkan pada tabel 6 .

Tabel 6 Pengaruh Langsung terhadap

Variabel Kompetensi Pustakawan

\begin{tabular}{|l|c|}
\hline \multicolumn{1}{|c|}{ Varibel Kompetensi Pustakawan $(\mathbf{X})$} & Nilai \\
\hline Pengetahuan $(\mathbf{X})$ & \\
\hline Pustakawan memahami tentang pelayanan perpustakaan $\left(\mathrm{X}_{1.1}\right)$ & 0,760 \\
\hline Pustakawan mampu dalam penggunaan komputer dan teknologi lain di perpustakaan $\left(\mathrm{X}_{1.2}\right)$ & 0,638 \\
\hline Pustakawan memahami kebutuhan referensi pemustaka/ pengunjung perpustakaan $\left(\mathrm{X}_{1.3}\right)$ & 0,631 \\
\hline Ketrampilan Interpersonal $(\mathrm{X} 2)$ & \\
\hline Pustakawan menyenangkan dalam melayani $\left(\mathrm{X}_{2.1}\right)$ & 0,728 \\
\hline Pustakawan proaktif membantu pemustaka $\left(\mathrm{X}_{2.2}\right)$ & 0,733 \\
\hline Pustakawan memberikan saran/solusi ketika pemustaka mengalami masalah layanan $\left(\mathrm{X}_{2.3}\right)$ & 0,693 \\
\hline Sikap Profesional $(\mathrm{X3})$ & \\
\hline Pustakawan selalu mengecek kartu anggota/KTM pada saat melakukan peminjaman $\left(\mathrm{X}_{3.1}\right)$ & 0,216 \\
\hline Pustakawan melakukan pengawasan terhadap pelanggaran peminjam koleksi $\left(\mathrm{X}_{3.2}\right)$ & 0,560 \\
\hline $\begin{array}{l}\text { Pustakawan fokus melayani pemustaka (tidak sambil menerima telepon, menggunakan } \\
\text { sosial media, main game dll) }\left(\mathrm{X}_{3.3}\right)\end{array}$ & $\mathbf{0 , 6 2 8}$ \\
\hline
\end{tabular}

Sumber: UPT Perpustakaan UNEJ, Data diolah, 2019

Tabel 6 menunjukkan nilai tertinggi pada indikator "Pustakawan Memahami tentang Pelayanan Perpustakaan" $\left(\mathrm{X}_{1.1}\right)=$ 0,760 . Indikator ini menunjukkan bahwa $76 \%$ pustakawan mengetahui secara benar tentang layanan yang disajikan di Perpustakaan UNEJ. Pustakawan mempunyai keahlian dalam pencarian sumber informasi baik koleksi cetak maupun non cetak sehingga pemustaka merasa puas. Samosir (2005) menyatakan bahwa kualitas layanan berpengaruh signifikan terhadap kepuasan mahasiswa dalam neggunkan Perpustakaan Universitas Sumatra Utara.

Upaya UPT Perpustakaan UNEJ dalam meningkatkan kompetensi pustakawan dan kualitas layanan adalah ikut serta dalam uji sertifikasi dan uji kompetensi, berpartisipasi dalam kegiatan kepustakawanan, memberi kesempatan kepada SDM perpustakaan untuk menempuh pendidikan ke jenjang yang lebih tinggi.

Sedangkan output yang menjelaskan hubungan antara variabel laten dan indikator pengaruh tidak langsung Outer Model (Weights of Loading) menunjukkan nilai terbesar pada indikator "Pustakawan menyenangkan dalam melayani” $\left(\mathrm{X}_{2.1}\right)=0,9212$. Secara tidak langsung pustakawan memberi konstribusi penilaian tertinggi $(92,21 \%)$ dalam pelayanan yang menyenangkan.

\section{SIMPULAN DAN SARAN Simpulan}

Berdasar analisis penelitian, maka dapat disimpulkan bahwa: 
1. Kompetensi pustakawan(X) berpengaruh signifikan terhadap Kualitas Layanan $(83,1 \%)$.

2. Varibel Kompetensi Pustakawan (X) dominan berpengaruh secara langsung terhadap kualitas layanan adalah pada indikator pengetahuan, yaitu Pustakawan memahami pelayanan $(76 \%)$

3. Variabel Kompetensi Pustakawan (X) berpengaruh secara tidak langsung terhadap kualitas layanan adalah dominan pada indikator pengetahuan, yaitu Pustakawan menyenangkan dalam melayani $\left(\mathrm{X}_{2.1}\right)$ sejumlah $92,12 \%$.

\section{Saran}

Untuk meningkatkan kualitas layanan perpustakaan perlu meningkatkan kompetensi pustakawan berupa kegiatan peningkatan pengetahaun tentang layanan perpustakaan.

\section{DAFTAR PUSTAKA}

Aji, R. F. (2010). Pengembangan Garuda (Garba Rujukan Digital) Sebagai Sumber Rujukan Karya Ilmiah Di Indonesia. Seminar Nasional Aplikasi Teknologi Informasi (SNAT). Seminar Nasional Aplikasi Teknologi Informasi (SNATI), 19 Juni 20, A-98-A-102. Retrieved from https://journal.uii.ac.id/Snati/article/ view/1870

Anggraini, L. (2015). Perbedaan Self-Efficacy Dan Self Regulated Learning Antara Siswa Lakilaki Dan Perempuan Di SMA Negeri 1 Selatpanjang. Retrieved from http://repository.uin-suska.ac.id/6795/

Aryani, D., \& Rosinta, F. (2010). Pengaruh Kualitas Layanan terhadap Kepuasan Pelanggan dalam Membentuk Loyalitas Pelanggan.Bisnis \& Birokrasi. Jurnal Ilmu Administrasi Dan Organisasi, Volume 17, 114-126. Retrieved from http://journal.ui.ac.id/jbb/article/ viewFile/632/617 diakses 16 April 2019
Budiati, I.dkk. (2018). Statistik Gender Tematik: Profil Generasi Milenial Indonesia. Jakarta: Kementerian Pemberdayaan Perempuan dan Perlindungan Anak.

Dwirani, Y. (2016). Hubungan Kompetensi SDM Perpustakaan Dengan Kualitas Layanan Digital Di Perpustakaan Smk Negeri 2 Palembang (UIN Raden Fatah Palembang). Retrieved from http:// eprints.radenfatah.ac.id/184/

Fahmi, I. (2017). Indonesia OneSearch dan Biblio Metric Analysis. DIY: FPPTI.

Gaol, A. L., Hidayat, K., \& Sunarti. (2016). Pengaruh Kualitas Produk terhadap Tingkat Kepuasan Konsumen dan Loyalitas Konsumen (Survei pada Mahasiswa S1 Fakultas Ilmu Administrasi Tahun Akademik 2012/2013 Universitas Brawijaya yang Menggunakan Smartphone Samsung). Jurnal Administrasi Bisnis, 28 N0.1, 1-8.

Ghozali, I., \& Latan, H. (2012). Partial Least Square: Konsep, Teknik dan Aplikasi SmartPLS 2.0 M3. Semarang: Badan Penerbit Universitas Diponegor.

Griffin, J. (2005). Customer Loyalty: Menumbuhkan \& Mempertahankan Kesetiaan Pelanggan (Revisi). Jakarta: Erlangga.

Irawan, D., \& Japarianto, E. (2013). Analisa Penngaruh Kualitas Produk Terhadap Loyalitas Melalui Kepuasan Sebagai Variabel Intervening Pada Pelanggan Restoran Por Kee Surabaya. Jurnal Manajemen Pemasaran, Vol. 1, No, 1-8.

Karygiannis, T. (2007). Guidelines for Securing Radio Frequency Identification (RFID) Systems. Gaithersburg: NIST.

Kotler, P., \& Teguh., T. H. (2002). Manajemen Pemasaran. (Edisi Mile). Jakarta: Prehalindo. 
Kurniasih, N. (2015). Kualifikasi Pustakawan di Era Digital. Prosiding Semiloka Nasional Kepustakawanan Indonesia (Vol. 19-21 Agus). Bandung.

Lasa. (1998). Kamus istilah perpustakaan. Yogyakarta: Gajah Mada University Press.

Perpustakaan Nasional RI. (2012). Keputusan Menteri Tenaga Kerja dan Transmigrasi Republik Indonesia Nomor 83 Tahun 2012 tentang Penetapan Rancangan Standar Kompetensi Kerja Nasional Indonesia Sektor Jasa Kemasyarakatan, Sosial Budaya, Hiburan, dan Perorangan Lainnya Bidang Perpustakaan m. Jakarta: Perpustakaan Nasional RI.

Perpustakaan Nasional RI. (2017). Peraturan Kepala Perpustakaan Nasional Republik Indonesia Nomor 11 Tahun 2015 Tentang Petunjuk Teknis Jabatan Fungsional Pustakawan Dan Angka Kreditnya. Jakarta.

Prasetyo, B. (2012). Menilik Kesiapan Dunia Ketenagakerjaan Indonesia Menghadapi MEA. Jurnal RechtsVinding, Media Pembinaan Hukum Nasional. https://doi. org/10.1007/s 13398-014-0173-7.2

Rosita, R., Marhanah, S., \& Wahadi, W. H. (2016). Pengaruh Fasilitas Wisata Dan Kualitas Pelayanan Terhadap Kepuasan Pengunjung Di Taman Margasatwa Ragunan Jakarta. Jurnal Manajemen Resort Dan Leisure, Vol 13, No.1

https://doi.org/https://doi.org/10.17509/ jurel.v13i1.2134

Samosir, Z. Z. (2005). Pengaruh Kualitas Pelayanan Terhadap Kepuasan Mahasiswa Menggunakan Perpustakaan USU. Jurnal Studi Perpustakaan Dan Informasi, 1 No.1.
Shahreza, M. (2017). Komunikator Politik Berdasarkan Teori Generasi. Nyimak (Journal of Communication), 1(1). https:// doi.org/10.31000/nyimak.v1i1.273

Singarimbun, M. (1989). Metode Penelitian Survai.pdf. In LP3ES.

Suwarno, W. (2016). Mengembangkan SDM Perpustakaan Dalam Rangka Menuju World Class University Libraria. LIBRARIA: Jurnal Perpustakaan, Vol. 4, No. Retrieved from http://journal. stainkudus.ac.id/index.php/Libraria/ article/view/1241/pdf diakses 1 April $2019 \% 0 \mathrm{~A}$

Tjiptono, F. (2004). Prinsip-Prinsip Total Quality Service. Yogyakarta: Andi Offset.

Wuryandani, D. (2015). Peluang Dan Tantangan Sdm Indonesia Menyongsong Era. Info Singkat: Ekonomi Dan Kebijakan Publik.

http://e-resources.perpusnas.go.id/ diakses 3 Desember 2019

www.unej.ac.id diakses 3 Desember 2019 